\title{
Screening of Vibrio isolates to develop an experimental infection model in the Pacific oyster Crassostrea gigas
}

\author{
Mélanie Gay, Franck C. J. Berthe, Frédérique Le Roux* \\ Laboratoire de Génétique et Pathologie, Institut français de recherche pour l'exploitation de la mer (IFREMER), \\ 17390 La Tremblade, France
}

\begin{abstract}
In an attempt to develop a reproducible experimental model of bacterial infection in Crassostrea gigas, oysters taken from very localised sub-populations suffering natural mortality outbreaks were used in cohabitation trials under laboratory conditions. From these trials, a collection of Vibrio strains was isolated from moribund and healthy oysters. In a second step, strains were experimentally tested for virulence by means of injection into healthy oysters. This screening revealed a span of virulence among isolated strains from none to medium. When pooling injected strains, results suggest increased virulence. Vibrio strains may have additive/synergistic action leading to higher $C$. gigas mortality rates in experimental challenges. Although the study initially aimed to develop a simple experimental model, a complex of interactions emerged between several bacterial strains during the pathogenic process in their molluscan host. Selected strains provide a suitable model of experimental disease for further studies and better understanding of bacterial interaction and pathogenesis in C. gigas.
\end{abstract}

KEY WORDS: Vibrio splendidus $\cdot$ Virulence $\cdot$ Agonism $\cdot$ Antagonism Resale or republication not permitted without written consent of the publisher

\section{INTRODUCTION}

While experimental transmission of mollusc diseases under laboratory conditions has sometimes been achieved (Bachère et al. 1986, Le Deuff et al. 1994, Chu 1996, Hervio et al. 1996, Audemard et al. 2002), the lack of a reproducible disease model is broadly recognised as an impediment to scientific investigations (Mialhe et al. 1995, Berthe et al. 1998). Diseases caused by non-cultivable pathogenic agents, unknown agents or agents having a complex life-cycle present the most difficulties. Considering this, bacterial infection has the potential for further development of an experimental disease model.

Bacterial diseases in molluscs have been described mainly for the larval stage and in hatcheries, with a marked predominance of the genus Vibrio (Tubiash et al. 1965, Brown \& Losee 1978, Disalvo et al. 1978, Elston \& Leibovitz 1980a,b, Jeffries 1982, Hada et al. 1984, Lambert et al. 1998, Sugumar et al. 1998). Vib- riosis has also been reported in juvenile and adult molluscs. For example, Vibrio tapetis is the aetiological agent of brown ring disease in the Japanese clam Ruditapes philippinarum (Paillard \& Maes 1990, Borrego et al. 1996), and $V$. harveyi has been associated with a severe epizootic outbreak in the abalone Haliotis tuberculata (Nicolas et al. 2002). In the Pacific oyster Crassostrea gigas, 2 potentially pathogenic strains were identified as V. splendidus (Lacoste et al. 2001, Waechter et al. 2002, Le Roux et al. 2002), and were associated with summer mortality syndrome outbreaks (Goulletquer et al. 1998).

Vibrio pathogenesis has only been documented in a limited number of molluscan diseases. To date, descriptions were made of $V$. tapetis infection in Ruditapes philippinarum, $V$. anguillarum in Crassostrea gigas larvae, and $V$. lentus in Octopus vulgaris (Elston \& Leibovitz 1980a,b, Elston et al. 1982, Oubella et al. 1994, Paillard et al. 1994, Allam et al. 2000, Farto et al. 2003). In adult oysters, vibriosis-induced host tissue 
alteration and immune response, as well as virulence mechanism and regulation, are still poorly understood. This could be explained by the absence of clinical signs preceding death of shelled molluscs, the high diversity of the Vibrio species involved and the opportunistic status of different strains (Le Roux et al. 2002, Waechter et al. 2002). The development of a robust experimental model would therefore represent major progress.

The main objective of this study was to isolate Vibrio strains and screen them for virulence in order to develop an experimental model of vibriosis in Crassostrea gigas. The first step of this work was to establish a collection of Vibrio potentially pathogenic to C. gigas. To achieve this, live oysters from very localised sub-populations suffering summer mortality outbreaks were collected in different areas. In order to enhance the chances of selecting oysters that carry pathogenic Vibrio spp., cohabitation experiments were conducted under laboratory conditions, and observed transmissible events enabled us to identify candidates for bacterial isolation. During these trials, a collection of Vibrio strains was isolated from moribund and healthy animals followed by their characterisation by means of gyrase subunit $(g y r B)$ gene sequencing (Le Roux et al. 2004).

The second step of the study was to select virulent strains. The screening of strains-either individual or pooled strains - was performed by injection challenges using Crassostrea gigas after pre-screening in clams Ruditapes philippinarum, given the higher susceptibility of the latter species to bacterial infection, as has been previously demonstrated (Le Roux et al. 2002).

\section{MATERIALS AND METHODS}

Cohabitation experiments. During summer 2001, live oysters (neighbouring oysters displaying a mortality rate of $>20 \%$ ), were collected from several beds along the Atlantic coast of France and from 1 batch from a hatchery (Table 1$)$. These oysters $(n=15$, referred to as 'field batch') were kept in aquaria along with healthy oysters from populations which had never suffered from mortality (IFREMER hatchery, $\mathrm{n}=15$, referred to as 'sentinel batch'). Experiments were performed for $1 \mathrm{wk}$ in $2.5 \mathrm{l}$ aquaria filled with $5 \mu \mathrm{m}$ filtered seawater, under static conditions at $20^{\circ} \mathrm{C}$ with aeration. Oysters were fed daily with a mixture of Isochrysis galbana and Chaetoceros calcitrans. During the experiment, sentinel oysters displaying a weakness of adduction activity (moribund oysters) were sacrificed, and the haemolymph was collected for bacterial analysis. For each cohabitation experiment, controls consisted of sentinel oysters maintained under the same conditions; haemolymph samples were collected from healthy animals as described above.
Bacterial isolation. Isolation was performed from the haemolymph in order to avoid contamination from the digestive tract flora where Vibrio is predominant (Prieur 1982). Samples of haemolymph were pooled from 3 oysters, serial dilutions spread onto thiosulfate citrate bile sucrose agar (TCBS, Diagnostic Pasteur) and incubated for $48 \mathrm{~h}$ at $20^{\circ} \mathrm{C}$. Three colonies of each macroscopic type were selected and isolated for subculture. The origin and source of the isolations are given in Table 1. All strains were further sub-cultured on tryptic soy agar (TSA) supplemented with $2 \% \mathrm{NaCl}$ (Difco) at $20^{\circ} \mathrm{C}$, and were stored at $-80^{\circ} \mathrm{C}$ in basal medium $\left(1 \% \mathrm{w} / \mathrm{v}\right.$ peptone, $0.1 \% \mathrm{w} / \mathrm{v} \mathrm{MgSO}_{4} \cdot 7 \mathrm{H}_{2} \mathrm{O}$, $10 \% \mathrm{v} / \mathrm{v}$ glycerol; $\mathrm{pH} 7.2)$ in the collection of the EU Community Reference Laboratory for Mollusc Diseases (IFREMER, La Tremblade, France).

Genotyping. Bacterial DNA was prepared according to Sambrook et al. (1989). PCR amplification of the DNA gyrase subunit ( $g y r B)$ was achieved with primers and methods previously described (Yamamoto \& Harayama 1995). Amplified products were purified using a gel extraction kit (Qiagen). Sequencing was carried out using the Sequitherm Excell II kit (Epicentre) and a Li-Cor DNA sequencer (ScienceTec) according to the manufacturer's instructions.

Phylogenetic analyses. GyrB sequences were aligned and phylogenetic analyses were performed using Seaview and Phylo-win programs (Galtier et al. 1996). Phylogenetic trees were built using the BIONJ method (Gascuel 1987) applied to Kimura's 2-parameter distances. Reliability of topologies was assessed by the bootstrap method with 1000 replicates.

Experimental challenges. Bacteria were grown at $20^{\circ} \mathrm{C}$ for $36 \mathrm{~h}$ in marine broth (Diagnostic Pasteur) and harvested in sterile seawater $\left(121^{\circ} \mathrm{C}\right.$ for $\left.15 \mathrm{~min}\right)$ at a

Table 1. Crassostrea gigas. Number of moribund oysters obtained after $8 \mathrm{~d}$ of cohabitation experiments for field $(\mathrm{n}=$ $15)$ and sentinel $(n=15)$ batches. Sentinel batches for which bacteriological analysis was conducted are underlined

\begin{tabular}{|c|c|c|}
\hline \multirow[t]{2}{*}{$\begin{array}{l}\text { Origin/ } \\
\text { reference }\end{array}$} & \multicolumn{2}{|c|}{$\begin{array}{c}\text { Cumulative mortality at } 8 \mathrm{~d} \\
\text { post cohabitation }\end{array}$} \\
\hline & Field batch & Sentinel batch \\
\hline Arcachon 01-84 & 15 & 15 \\
\hline$\overline{\text { Arcachon 01-88 }}$ & 15 & $\overline{8}$ \\
\hline Arcachon 01-90 & 15 & 14 \\
\hline Fouras 01-92 & 5 & $\overline{10}$ \\
\hline$\overline{\text { Fouras 01-94 }}$ & 5 & 0 \\
\hline Fouras 01-116 & 8 & 9 \\
\hline Perquis J1 & 15 & 11 \\
\hline Perquis J8 & 15 & 15 \\
\hline $\begin{array}{l}\text { Hatchery } \\
\end{array}$ & 15 & $\overline{12}$ \\
\hline Trinité 01-105 & 0 & $\overline{2}$ \\
\hline Trinité 01-106 & 6 & 3 \\
\hline Trinité 01-111 & 14 & $\underline{15}$ \\
\hline
\end{tabular}


concentration of 4 to $8 \times 10^{8}$ colony forming units (CFU) $\mathrm{ml}^{-1}$ calculated by reading the optical density (OD) at $600 \mathrm{~nm}$ with a spectrophotometer (Biophotometer, Eppendorf). This bacterial concentration was confirmed by enumeration on marine agar plates using a conventional dilution plating technique with incubation at $20^{\circ} \mathrm{C}$ for $2 \mathrm{~d}$.

A pre-screening of virulent strains was performed using the clam model. Since we could not individually test all 125 strains, bacterial isolates from a cohabitation experiment were injected from a pool of 3 to 5 strains. For this, equal volumes of each strain at the concentration of $4 \times 10^{8} \mathrm{CFU} \mathrm{ml}^{-1}$ were mixed and $100 \mu \mathrm{l}$ of this mixture $\left(4 \times 10^{7} \mathrm{CFU}\right)$ was injected into the adductor muscle of adult clams ( $\mathrm{n}=30$, size 3 to $5 \mathrm{~cm}$ ). A negative control consisted of 30 clams injected with sterile seawater. The clams were kept out of water overnight at $20^{\circ} \mathrm{C}$ and were then maintained for $1 \mathrm{wk}$ in aerated seawater ( 30 clams in $2.5 \mathrm{l}$ ) at $20^{\circ} \mathrm{C}$. Animals were fed with phytoplankton every day, as described above.

Crassostrea gigas spat originated from captive samples and measured 4 to $6 \mathrm{~cm}$. To anaesthetise oysters and open the valves, spat were first kept for $2 \mathrm{~h}$ in a $\mathrm{MgCl}_{2}$ bath at a final concentration of $50 \mathrm{~g} \mathrm{l}^{-1}(2 / 3 \mathrm{v} / \mathrm{v}$ seawater/freshwater) and supplemented with phytoplankton. A volume of $50 \mu \mathrm{l}$ of the bacterial suspension (pool or unique, total $4 \times 10^{7} \mathrm{CFU}$ ind. ${ }^{-1}$ ) was inoculated by injection into the adductor muscle $(n=30)$. Negative controls consisted of a group of 30 oysters injected with sterile seawater. Immediately after injection, oysters were transferred to the aquarium (30 oysters in $2.5 \mathrm{l}$ ) containing aerated filtered seawater at $20^{\circ} \mathrm{C}$ kept under static conditions, and fed as described previously.

Statistical analysis. Four experimental infections were carried out in triplicate. They consisted of injecting sterile seawater (SSW) or the strain (alone/pooled) in the adductor muscle of batches of 30 oysters as described previously. The least significant difference test was carried out on the arcsinus of the mean cumulated mortality rate at $3 \mathrm{~d}$ post injection, with a $5 \%$ threshold (Cochran \& Cox 1957).

\section{RESULTS}

\section{Cohabitation}

Table 1 shows the results from 12 field batches of live oysters Crassostrea gigas that were taken from populations which suffered mortality events in 5 geographic areas (4 in the field, 1 in hatchery) and subsequently maintained with healthy spat, as described in the 'Materials and methods'. In 11/12 field batches, mortality was observed 1 to $3 \mathrm{~d}$ after the experiment began. Seven batches presented a mortality rate higher than $90 \%$. In the sentinel batch, mortality occurred 3 to $5 \mathrm{~d}$ after the experiment started, with a cumulative mortality rate above $50 \%$ in $9 / 12$ cases at $8 \mathrm{~d}$ post cohabitation. No mortality was observed in the aquaria containing only sentinel oysters (controls). Sentinel batches used for bacterial isolation (Table 1) were shown to be herpes virus free by PCR (data not shown). Strains 1 to 82 were isolated from diseased animals, whereas Strains 83 to 125 were isolated from healthy controls.

\section{Genotypic characterisation of strains}

Sequences were collected and analysed from 104 strains. Cluster analysis by phylogenetic study based on partial gyrB sequence (588 bp) demonstrated that the majority of strains (68/104 analysed), isolated from diseased or healthy oysters, were included in the recently described Vibrio splendidus polyphyletic group (Le Roux et al. 2004). Other strains were included in clades containing $V$. aestuarianus (10 strains), V. mediterranei (8 strains) and V. pelagia (4 strains) type strains. Fourteen strains were included in distinct clades and have not yet been identified. Concerning the strains selected after experimental challenge, the phylogenetic analysis is given in Fig. 1. The

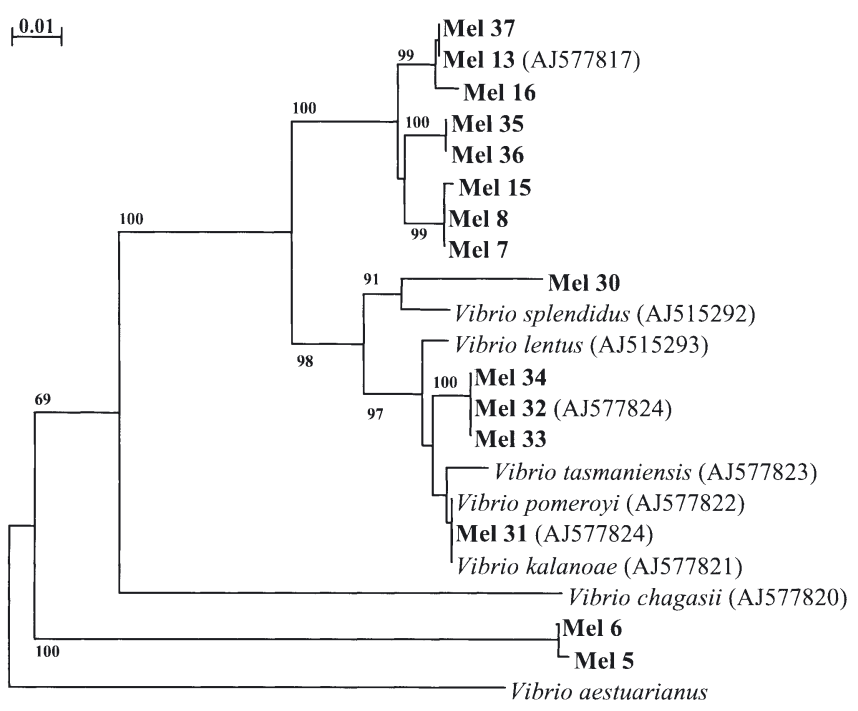

Fig. 1. Phylogenetic tree of partial gyrB sequences for Vibrio splendidus related strains and 16 strains selected by screening in experimental challenge; 588 gap-free sites were compared. The $V$. aestuarianus homologue Strain 01/32, kindly provided by J. L. Nicolas (IFREMER), was used as outgroup. Horizontal branch lengths are proportional to evolutionary divergence. Significant bootstrap values in percent (>80\%) of 1000 replicates appear next to the corresponding branch. EMBL accession numbers follow strain names 

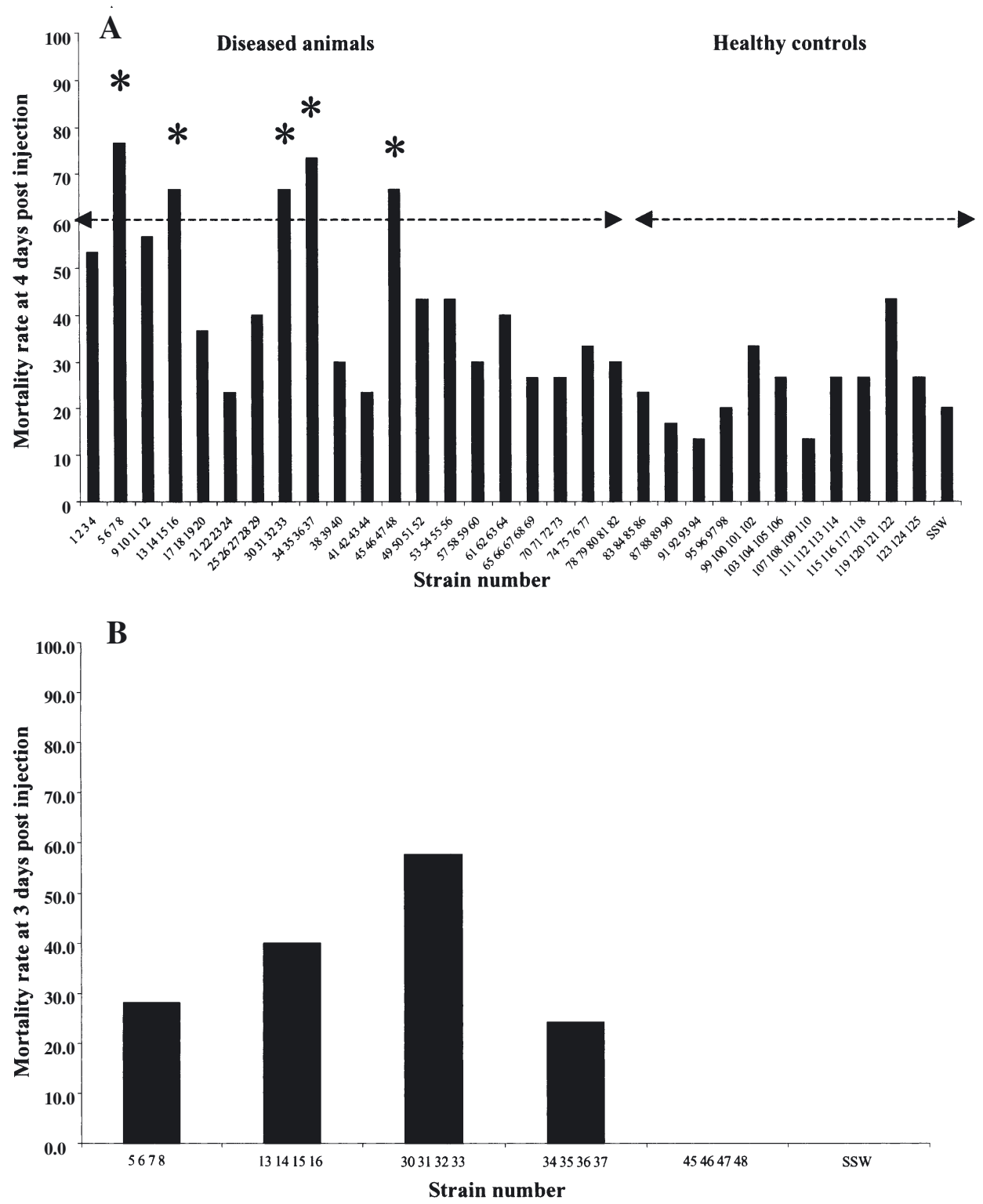

Fig. 2. (A) Ruditapes philippinarum and (B) Crassostrea gigas. Mortality rate (\%) at 4 or 3 d post injection, respectively, of pooled strains to batches of (A) 30 clams or (B) 30 oysters. Strains 1 to 29, 30 to 40, 41 to 56, 57 to 69, and 70 to 82 were isolated after cohabitation experiments with oysters, sampled, respectively, in Arcachon, Fouras, Perquis, hatchery and Trinité. Strains 83 to 125 were isolated from healthy animals. Sterile sea water (SSW) was injected as negative control. Asterisks in (A) mark the Vibrio pools causing highest mortality, which were then used for oysters (B)

first clade, supported by a bootstrap value of $100 \%$, included Strains $37,13,16,35,36,15,8$ and 7 . This clade could be divided in subgroups according to bootstrap values of 99 to $100 \%$. A second clade, showing a bootstrap value of $91 \%$, grouped the $V$. splendidus type strain and Strain 30. V. kanaloae, V. pomeroyi, V. tasmaniensis and $V$. lentus were clustered with Strains 34, 32, 33 and 31. GyrB phylogenetic analyses did not lead to a clear discrimination of these species, in agreement with a previous study (Le Roux et al. 2004). Strains 5 and 6 were clearly discriminated from $V$. splendidus related strains and clustered in a 4 th clade.

\section{Screening of virulent strains by experimental challenge}

The first screening of virulent strains was performed in clams. Three to 5 strains isolated from the same experimental batch described above were pooled (31 groups) and injected in oysters (Fig. 2A). An equal volume of sterile seawater was injected as a negative control (SSW). The 5 pools of Vibrio showing the highest mortality rates (68 to $78 \%$ ), marked by an asterisk, were selected to be injected in oysters (Fig. 2B). Three days post-injection, no mortality was observed in the 
case of pooled Strains 45, 46, 47, 48 and the SSW. Four pools of bacterial strains induced 23 to $58 \%$ mortality, and these were selected for further experimental infections.

The first pool tested contained Strains 30, 31, 32 and 33 isolated from a unique geographic area and mortality event (Fig. 3A). These strains were injected alone, as well as in pools of 2, 3 or 4 strains. Three days post-injection, Strains 30,31, 32 and 33 gave mortality rates of $12,30,22$ and $25 \%$, respectively, which was lower than the mortality obtained with grouped bacteria ( $40 \%$ ). When Strains 31,32 or 33 were injected together with Strain 30, the mortality rate was similar to the 4 strains pooled. However, the highest mortality rate was obtained when Strain 31 was injected with Strain 32 or $33(60 \%)$.

In order to evaluate the reproducibility of this phenomena, 4 experimental infections were carried out in triplicate. A least significant difference test demonstrated that the virulence of Strains 31 and 32 injected together was significantly higher than when injected individually.

Different quantities $\left(10^{5}\right.$ to $\left.10^{7}\right)$ of Strains 31 and/or 32 were tested by injection, and $10^{7} \mathrm{CFU}$ ind. ${ }^{-1}$ was demonstrated to be necessary to induce significant mortality.

Additional experiments were conducted with strains belonging to other selected pools (Fig. 3B). Strains 7 and 8 had a higher virulence than Strains 5 and 6 . Strain 5 injected with 6,7 and 8 yielded a mortality rate equivalent to those induced by individual strains. The highest levels of mortality were obtained when Strains 7 and 8, 6 and 8, or 6 and 7 were coinjected.

Strain 15 injected alone induced the highest mortality rate $(55 \%)$, and Strain 16 the lowest $(5 \%)$ (Fig. 3C). Cumulative effects were observed when Strains 13 or 14 were injected with Strain 16.

Strain 35 injected alone induced the highest mortality rate (50\%) (Fig. 3D). A cumulative effect was observed when Strain 34 was injected with Strain 37.

A decreased mortality rate was observed when Strains 15 or 35 , presenting the highest virulence, were injected with other strains.

\section{DISCUSSION}

The development of an experimental model of vibriosis in Crassostrea gigas represents a pivotal step in the study of this disease, in addition to a better understanding of the modulation of host immune response with respect to pathogen response and physiological stress.
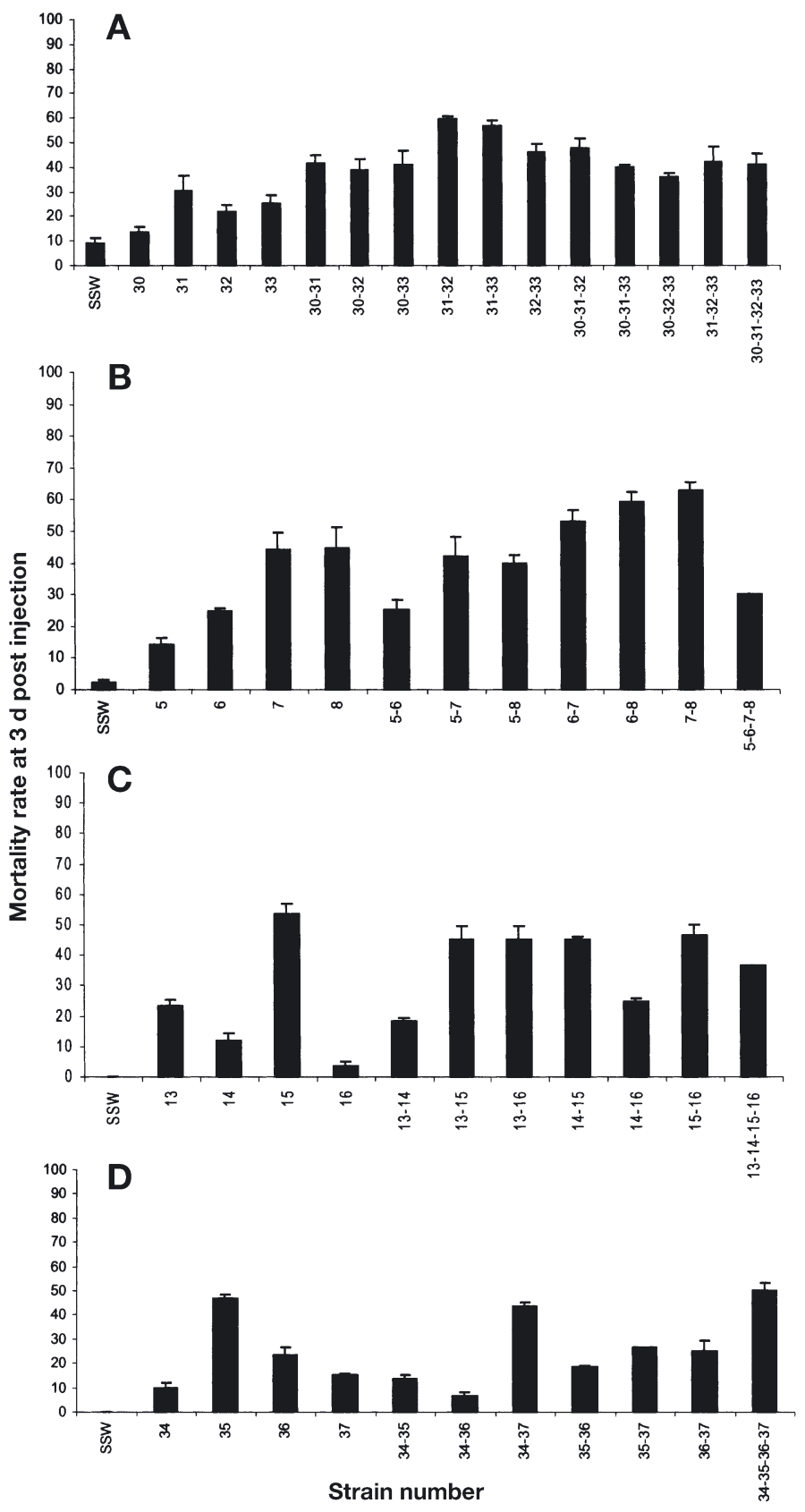

Fig. 3. Crassostrea gigas. Mortality rate (\%) in batches of 30 oysters at 3 d post injection of strains: (A) Strains 30, 31, 32, and 33 injected individually, or in mixtures of 2,3 and 4 strains; (B) Strains 5, 6, 7, and 8 injected individually or in mixtures of 2 and 4 ; (C) Strains 13, 14, 15, 16 injected individually, or in mixtures of 2 and 4; and (D) Strains 34, 35, 36, and 37 injected individually, or in mixtures of 2 and 4 . Sterile seawater (SSW) was injected as negative control. All experiments were performed in triplicate

In this study, strains were isolated from diseased oysters and healthy controls following cohabitation experiments. The molecular characterisation showed a genetic diversity suggesting that several species and 
strains could have been involved in these selected mortality events. Most of the strains from the established collection belong to the Vibrio splendidus polyphyletic group (Le Roux et al. 2004), isolated from either diseased or healthy animals. The strains belonging to a given clade, as delineated by the gyrB analysis (Fig. 1), displayed virulence ranging from low to medium induced mortality as observed by experimental exposure. These data show no relation between taxonomic affiliation and potential virulence. This precludes the use of bacterial identification in anticipating the cause or origin of mortality. A practical consequence is that the virulence of isolated strains has to be assessed by experimental challenge. This also emphasises the need for identification of new targets for diagnostic tools, and underlines the need for further investigations of virulence to be undertaken based on comparative approaches in the $V$. splendidus group.

For the purpose of pre-screening virulent bacterial strains, isolates were initially injected as pools of strains in clams Ruditapes philippinarum. This was justified by a high susceptibility of this mollusc species to infection by Vibrio splendidus-related strains (Le Roux et al. 2002), as well as robust reproducibility of experimental results (unpubl. data). In this host, 5 pools out of 31 induced increased mortality rates, i.e. higher than those observed in controls. Among these 5 pools, 4 also caused mortality of oysters Crassostrea gigas, but at a lower level. However, one cannot exclude the possibility that strains could be pathogenic for oysters and not for clams. This could have occurred and requires further challenge trials to be more fully assessed.

The results obtained during the present study have demonstrated that some strains are virulent for both host species: clams and oysters. Independently of the host they infect, these strains could share a common mechanism-genetic and/or metabolic-providing potential for pathogenicity. The strains related to Vibrio splendidus are widely distributed in various environments (Nealson et al. 1993, Farto et al. 1999), they display an elevated genetic diversity and, according to the literature, may be associated with mortality in a broad range of aquatic animals (Nicolas et al. 1996, Sugumar et al. 1998, Gatesoupe et al. 1999, Lacoste et al. 2001, Waechter et al. 2002, Farto et al. 2003). In contrast, various Vibrio species, including V. pectinicida, $V$. tapetis, and $V$. penaecida, have a narrower host specificity and consistent pathogenicity. These contrasting situations raise questions regarding genome plasticity and, more specifically, virulence gene acquisition between bacterial strains.

Among the selected isolates, 2 strains, namely 15 and 35 , induced a mortality rate exceeding $50 \%$ when injected alone. These strains could be used for further development of an experimental infection model in
Crassostrea gigas. At this stage of the study, that only 2 strains responded to our quest could be seen as a poor result. Meanwhile, the use of pooled strains in our experimental protocol to perform injection challenges opened new prospects.

When these strains were injected in association with other strains, a decreased mortality rate was observed, suggesting an antagonistic mechanism. This antagonism was particularly clear when Strains 35 and 36 were co-injected. Antagonism between Vibrio species has previously been demonstrated. For instance, $V$. alginolyticus is known to reduce the pathogenicity caused by $V$. anguillarum and $V$. ordalii in fish (Austin et al. 1995) or infection with $V$. parahaemolyticus in shrimp (Garriques \& Arevalo 1995). Some strains, such as 36, may represent good candidates for probiotic development, because of the apparent protection they provide in addition to being part of the same microbial communities as pathogenic strain(s). This is practically implemented in hatcheries to improve seed production (Verschuere et al. 2000); however, this approach presents a potential problem with respect to reversion to and acquisition of virulence. For example, in our study Strain 37 reduces the pathogenicity of Strain 35, while boosting it in Strain 34 (Fig. 3D).

Strains 30, 31, 32 and 33 belonged to the most virulent pool. When analysing this pool by injection of single or multiple strains, strain pairs appeared to induce increased mortality rates similar to the Strain 34/37 association cited above (Fig. 3). The noteworthy association of Strains 31 and 32 induced significantly higher mortality than each of these strains injected individually. This effect was also observed with strains belonging to other pools, which suggests that different Vibrio strains share this ability, when associated, of an increased individual pathogenicity through additive/ synergistic mechanisms. Interactions between bacteria have previously been documented (Pasmore \& Costerton 2003). In addition, a positive collaboration of periodonto-pathogens has been suggested to induce abscess lesions in a mouse model (Ebersole et al. 1995).

Experimental challenges based on the injection of oysters with pooled cultures of Strains 31 and 32 show a statistically significant reproducibility, and this robustness was a major argument for retaining these strains in future experiments. This model enables the investigation of mechanisms leading to a cumulative effect of virulent strains. Experiments are in progress to elucidate the sequence of events or simultaneous interactions of the bacteria initiating and exacerbating the disease process. It is unknown whether the observed phenomenon reveals synergy-based effects on an interdependence of certain mechanisms of virulence, or additive effects stemming from reciprocal benefits and facilitated counteraction of the host immune response. 
To conclude, this study initially aimed at developing a simple experimental model, but led us to envision a complex of interactions between several bacterial strains during the pathogenic process in their molluscan host.

Acknowledgements. The authors acknowledge Mr Giraudeau and Mr Auvray for providing oysters and clams, Prof B. Austin, Drs F. Thompson, Tim Sharbel and D. Saulnier for critically reading the manuscript, and Dr. P. Soletchnik for statistical analyses. This study was carried out with financial assistance from the EU Community Reference Laboratory and Région Poitou-Charentes.

\section{LITERATURE CITED}

Allam B, Paillard C, Auffret M (2000) Alterations in hemolymph and extrapallial fluid parameters in the Manila clam, Ruditapes philippinarum challenged with its pathogen, Vibrio tapetis. J Invertebr Pathol 76:63-69

Audemard C, Le Roux F, Barnaud A, Collins C and 6 others (2002) Needle in a haystack: involvement of the copepod Paracartia grani in the life cycle of the oyster pathogen Marteilia refringens. Parasitology 124:315-323

Austin B, Stuckey LF, Robertson PAW, Effendi I, Griffith DRW (1995) A probiotic strain of Vibrio alginolyticus effective in reducing diseases caused by Aeromonas salmonicidae, Vibrio anguillarum and Vibrio ordalii. J Fish Dis 18:93-96

Bachère E, Comps M, Grizel H (1986) Infections experimentales de l'huître plate Ostrea edulis L. par le protozoaire Bonamia ostreae. In: Vivarès CP, Bonami JR, Jaspers E (eds) Pathology in marine aquaculture. European Aquaculture Society, Spec Publ No. 9. Bredene, Belgium, p $127-132$

Berthe FCJ, Pernas M, Zerabib M, Haffner P, Thébault A, Figueras AJ (1998) Experimental transmission of Marteilia refringens with special considerations for its life cycle. Dis Aquat Org 34:135-144

Borrego JJ, Castro D, Luque A, Paillard C, Maes P, Garcia MT, Ventosa A (1996) Vibrio tapetis sp. nov., the causative agent of the brown ring disease affecting cultured clams. Int J Syst Bacteriol 46:480-484

Brown C, Losee E (1978) Observations on natural and induced epizootics of vibriosis in Crassostrea virginica larvae. J Invertebr Pathol 31:41-47

Chu FLE (1996) Laboratory investigations of susceptibility, infectivity, and transmission of Perkinsus marinus in oysters. J Shellfish Res 15:57-66

Cochran WG, Cox GM (1957) Experimental designs, 2nd edn. John Wiley \& Sons, New York

Disalvo LH, Blecka J, Zebal R (1978) Vibrio anguillarum and larval mortality in a California coastal shellfish hatchery. Appl Environ Microbiol 35:219-221

Ebersole JL, Kesavalu L, Schneider SL, Machen RL, Holt SC (1995) Comparative virulence of periodontopathogens in a mouse abscess model. Oral Dis 1:115-28

Elston R, Leibovitz L (1980a) Detection of vibriosis in hatchery reared larval oysters: correlation between clinical, histological and ultrastructural observations in experimentally induced disease. Proc Nat Shellfish Assoc 70:122-123

Elston R, Leibovitz L (1980b) Pathogenesis of experimental vibriosis in larval American oysters, Crassostrea virginica. Can J Fish Aquat Sci 37:964-978
Elston R, Elliot EL, Colwell, RR (1982) Conchiolin infection and surface coating Vibrio: shell fragility, growth depression and mortalities in cultured oysters and clams, Crassostrea virginica, Ostrea edulis and Mercenaria mercenaria. J Fish Dis 5:265-284

Farto R, Montes M, Perez MJ, Nieto TP, Larsen JL, Pedersen K (1999) Characterization by numerical taxonomy and ribotyping of Vibrio splendidus biovar I and Vibrio scophthalmi strains associated with turbot cultures. J Appl Microbiol 86:796-804

Farto R, Armada SP, Montes M, Guisande JA, Perez MJ, Nieto TP (2003) Vibrio lentus associated with diseased wild octopus (Octopus vulgaris). J Invertebr Pathol 83(2): 149-56

Galtier N, Gouy M, Gautier C (1996) SEAVIEW and PHYLO_WIN: two graphic tools for sequence alignment and molecular phylogeny. Comput Appl Biosci 12: $543-548$

Garriques D, Arevalo G (1995) An evaluation of the production and use of a live bacterial isolate to manipulate the microbial flora in the commercial production of Penaeus vannamei postlarvae in Ecuador. In: Browdy CL, Hopkins JS (ed) Swimming through troubled water. Proc Spec Session on Shrimp Farming, Aquaculture '95. World Aquaculture Society, Baton Rouge, LA

Gascuel O (1987) BIONJ: an improved version of the NJ algorithm based on a simple model of sequence data. Mol Biol Evol 14:685-695

Gatesoupe FJ, Lambert C, Nicolas JL (1999) Pathogenicity of Vibrio splendidus strains associated with turbot larvae, Scophthalmus maximus. J Appl Microbiol 87:757-763

Goulletquer P, Soletchnik P, Le Moine O, Razet D, Geairon P, Faury N, Taillade S (1998) Summer mortality of the Pacific cupped oyster Crassostrea gigas in the Bay of Marennes Oléron (France). Proc ICES Mariculture Committee CM 1998/CC, Copenhagen, p 14-21

Hada HS, West PA, Lee JV, Stemmler J, Colwell RR (1984) Vibrio tubiashii sp. nov., a pathogen of bivalve molluscs. Int J Syst Bacteriol 34:1-4

Hervio D, Bower SM, Meyer GR (1996) Detection, isolation, and experimental transmission of Mikrocytos mackini, a microcell parasite of Pacific oysters Crassostrea gigas (Thunberg). J Invertebr Pathol 67:72-79

Jeffries VE (1982) Three Vibrio strains pathogenic to larvae of Crassostrea gigas and Ostrea edulis. Aquaculture 29: 201-226

Lacoste A, Jalabert F, Malham S, Cueff A, Gélébart F, Cordevant C, Lange M, Poulet SA (2001) A Vibrio splendidus strain is associated with summer mortality of juvenile oysters Crassostrea gigas in the Bay of Morlaix (North Brittany, France). Dis Aquat Org 46:139-145

Lambert C, Nicolas JL, Cilia V, Corre S (1998) Vibrio pectenicida sp. nov. a pathogen of scallop (Pecten maximus) larvae. Int J Syst Bacteriol 48:481-487

Le Deuff RM, Nicolas JL, Renault T, Cochennec N (1994) Experimental transmission of herpes-like virus to axenic larvae of Pacific oyster Crassostrea gigas. Bull Eur Fish Pathol 142:69-71

Le Roux F, Gay M, Lambert C, Waechter M, Poubalanne S, Chollet B, Nicolas JL, Berthe FCJ (2002) Comparative analysis of Vibrio splendidus-related strains isolated during Crassostrea gigas mortality events. Aquat Living Resour 15:251-258

Le Roux F, Gay M, Lambert C, Nicolas JL, Gouy M, Berthe FCJ (2004) Phylogenetic study and identification of Vibrio splendidus related strains based on gyrB gene sequences. Dis Aquat Org 58:143-150 
Mialhe E, Bachère E, Boulo V, Cadoret JP and 6 others (1995) Future of biotechnology-based control of disease in marine invertebrates. Mol Mar Biol Biotechnol 4:275-283

Nealson KH, Wimpee B, Wimpee C (1993) Identification of Vibrio splendidus as a member of the planktonic luminous bacteria from Persian Gulf and Kuwait region with LuxA probes. Appl Environ Microbiol 59:2684-2689

Nicolas JL, Corre S, Gauthier G, Robert R, Ansquer D (1996) Bacterial problems associated with scallop Pecten maximus larval culture. Dis Aquat Org 27:67-76

Nicolas JL, Basuyaux O, Mazurie J, Thebault A (2002) Vibrio carchariae, a pathogen of the abalone Haliotis tuberculata. Dis Aquat Org 50:35-43

Oubella R, Paillard C, Maes P, Auffret M (1994) Changes in hemolymph parameters in the manila clam Ruditapes philippinarum (Mollusca, Bivalvia) following bacterial challenge. J Invertebr Pathol 64:33-39

Paillard C, Maes P (1990) Etiologie de la maladie de l'anneau brun chez Tapes philippinarum: pathogénicité d'un Vibrio sp. CR Acad Sci Paris 310:15-20

Paillard C, Maes P, Oubella R (1994) Brown ring disease in clams. Annu Rev Fish Dis 4:219-240

Pasmore M, Costerton JW (2003) Biofilms, bacterial signaling, and their ties to marine biology. J Ind Microbiol Biotechnol 30:407-13

Editorial responsibility: David Bruno,

Aberdeen, UK
Prieur D (1982) The microflora of the digestive tract of marine bivalves: experimental study of the mussel, Mytilus edulis. Proc 7th Int Malacological Congress, August 31 to September 7, 1980, Perpignan. Malacologia 22:653-658

Sambrook J, Fritsch EF, Maniatis T (1989) Molecular cloning: a laboratory manual, 2nd edn. Cold Spring Harbor, New York

Sugumar G, Nakai T, Hirata Y, Matsubara D, Muroga K (1998) Vibrio splendidus biovar II as the causative agent of bacillary necrosis of Japanese oyster Crassostrea gigas larvae. Dis Aquat Org 33:111-118

Tubiash HS, Chanley Pe, Leifson E (1965) Bacillary necrosis, a disease of larval and juvenile bivalve mollusks. J Bacteriol 90:1036-1044

Verschuere L, Robaut G, Sorgeloos P, Verstraete W (2000) Probiotic bacteria as biological control agents in aquaculture. Microbiol Mol Biol 64:655-671

Waechter M, Le Roux F, Nicolas JL, Marissal E, Berthe F (2002) Characterisation of Crassostrea gigas spat pathogenic bacteria. CR Acad Sci 325:231-238

Yamamoto S, Harayama S (1995) PCR amplification and direct sequencing of $g y r B$ genes with universal primers and their application to the detection and taxonomic analysis of Pseudomonas putida strains. Appl Environ Microbiol 61:1104-1109

Submitted: October 29, 2003; Accepted: February 12, 2004 Proofs received from author(s): April 6, 2004 